\title{
BUSINESS MANAGEMENT AND ENTREPENEURSHIP FOR THE SANTRI AT PESANTREN AR-RAUDHATUL HASANAH MEDAN
}

\author{
Aisyah $^{1)}$, Fivi Rahmatus Sofiyah ${ }^{2)}$ Yeti Meliany Lubis ${ }^{3)}$ \\ ${ }^{1}$ Management Study Program, Universitas Sumatera Utara \\ putri_aiz@yahoo.co.id \\ ${ }^{2}$ Management Study Program, Universitas Sumatera Utara \\ fivi.rahmatus.sofiyah@gmail.com \\ ${ }^{3}$ Accounting Study Program, Universitas Sumatera Utara \\ meliany.yeti@yahoo.com
}

\begin{abstract}
The activity of devotion is done at Pesantren Ar-Raudhatul Hasanah Medan which the participants are santri who manage santri mart and student store, debriefing of finance management and management of business is very important to run business, sometimes important knowledge about entrepreneurship become part of learning process, entrepreneurship santri can better understand in running a business, according to their talents and interests. With training and demonstration patterns students can get information and learning.
\end{abstract}

\section{Keywords : Business Management, Entrepeneurship, and Social.}

\section{INTRODUCTION}

In this era of free competition, at this moment, the development of competencies and capacity of santri is a must. To be able to compete competitively in the global world, Islamic boarding schools are required to be able to produce products and alumni who are competent and productive in three ways. First, spiritually competent and productive. Second, socially competent and productive. Third, the alumni of pesantren must be economically competent and productive.

Pesantren Ar-Raudhatul Hasanah are one of the biggest Islamic boarding school at North Sumatera. A school that teaches common knowledge and religion,have a student that from various region outside of North Sumatera like Aceh,Jambi,Riau and even from abroad like Malaysia,Thailand and others,Homesick, and meeting their parents and family must they resist for their goals which is
success.Besides educating about religion and common knowledge the students(santri) are debriefed for entrepreneurship and how they manage a business and business management,the school taught and trust the students(santri) and how they run a business, the business that being currently managed by the students(santri) are the SANTRI MART and the student shop where the caretaker are all the students at Madrasah Aliyah(High school level) that sits in $11^{\text {th }}$ Grade.

With the business pattern that's being set by the school, automatically the school builds the students character that have an entrepreneur spirit,and a businessmen that Islamic. an early briefing about entrepeneurship will become the foundation of economic growth,the driving force of the real sector and and job avaibality that significant enough though entrepeneurship 
Aisyah. et al. Business Management and Entrepeneurship for the Santri At Pesantren Ar-Raudhatul Hasanah Medan.

development.uptil now the concept of entrepeneurship still growing.

According to Kraus Entrepeneurship is a manner,soul and skill to create something that's new and very valuable and usefull to theirself and otherperson. Entrepeneurship is a mental attitude and soul that always active and creative in creating, inventing, making and trying for increasing income in a business activity.

Someone that have an entrepeneurship character always dissatisfied with what they have achieved.An entrepreneur is a person that skilled to take the opportunity and developing their business with a purpose to increase their life value.Norman M.Scarborough dan Thomas W.Zimmerer(1993:5), "An entrepreneur is one who creates a new business in the face of risk and uncertainty for the purpose of achieving profit and growth by identifying opportunitiesand asembling thenecessary resources to capital zeonthose opportunities".

An entrepreneur are the people that have the skill to see and rate business opportunities, gathering sorces that needed to take the right action, and gaining profit also have the personality, character and the will to make their idea into reality in a creative way to achieve success or increasing their income. The point is, An entrepreneur are the people that have the entrepeneurship character built in dan applicate their entreupenership nature in their lif.In other words, an entreeneur are the people that have the creative sou and high innovatifity in their life.here's what the students do in when their managing their business

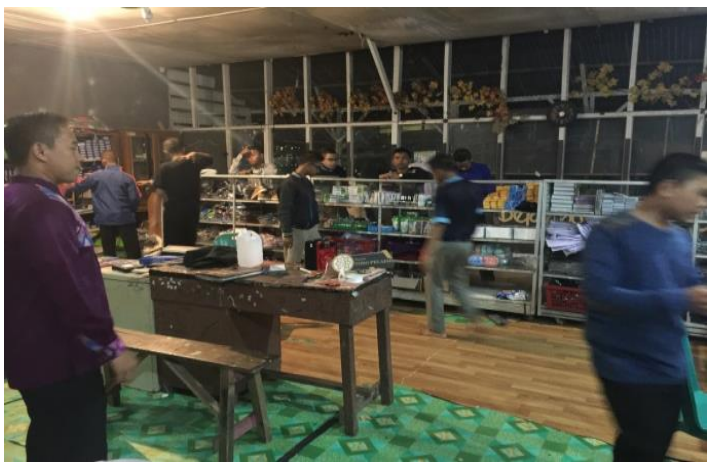

1.1 the partner location in devoting
Based from the thing above it can be said that their study about entrepeneurship already have a strong root at Pesantren ArRaudhatul Hasanah,it can even be inherited.so the devotion team will be revealing about their entrepeneurship education at pesantren raudhatul hasanah that already been implemented from the internalitation of entrepeneurship value and then continued with the proses of entrepeneurship education at pesantren Ar Raudhatul Hasanah.

In managing the economy at the boarding school,the teacher and the students are involved in it.the existence from various units is one of the education means in independence,entrepremeurship,sincerity and sacrifices field.all of the business that belongs to the school are run by the students or teacher,the results is being used for fulfilling the needs of the school,students,teacher and employee

\section{METHOD OF ACTIVITY}

\section{Time and Place of Devotion}

This activity of devotion is done at Pesantren Ar Raudhatul Hasanah, Medan, this activity is carried out on July for the journal report this devotion action placed at the santri's meeting hall and see directly (observation) the student businesses which are the Santri Mart and Student Store.

\section{Approaching Method}

The approach taken in handling the partnership problem was the descriptive technique with doing the three steps simultaneously according to Miles and Huberman which includes: 1) data reduction, which classify, directs, and scrapes away what's not needed for data organizing 2) Data displays, in which finding meaningful connected patterns and also to give a chance to create a conclusion 3) (conclusion drawing/verification) (Huberman, 1992:22). 


\section{DEVOTION ACTIVITY}

Based on the description of the main problem that has been stated from the sub chapter, therefore the activities to be carried out include the four problem solving aspect which are:

\section{Business Management Counseling}

Counseling of the business management concept provided by the USU Devotion Team from the Faculty of Economics and Business, the participants were students who sat in class XI. In this counseling they will be given a lecture to explain the principles of managing good business management so that students can understand and apply business management.

\section{Entrepreneurship Counseling}

Counseling of the entrepreneurship concept for students who were given by the Service Team from the USU Faculty of Economics and Business, the participants were the students who sat in class XI. In this counseling they will also be given a lecture to explain the principle of fostering a good early entrepreneurism so that students can understand and apply how the concept of becoming a businessman.

\section{Demonstration of Financial Statements}

Demonstration in this case is training activities to make simple financial reports to participants, and next training and demonstrations are carried out.

\section{Marketing Counseling}

Counseling of the marketing concept for students are given by the Service Team from the USU Faculty of Economics and Business, the participants were students who sat in class XI. In this counseling, a lecture will be given to explain good marketing principles so that students can understand and apply the concept of marketing.

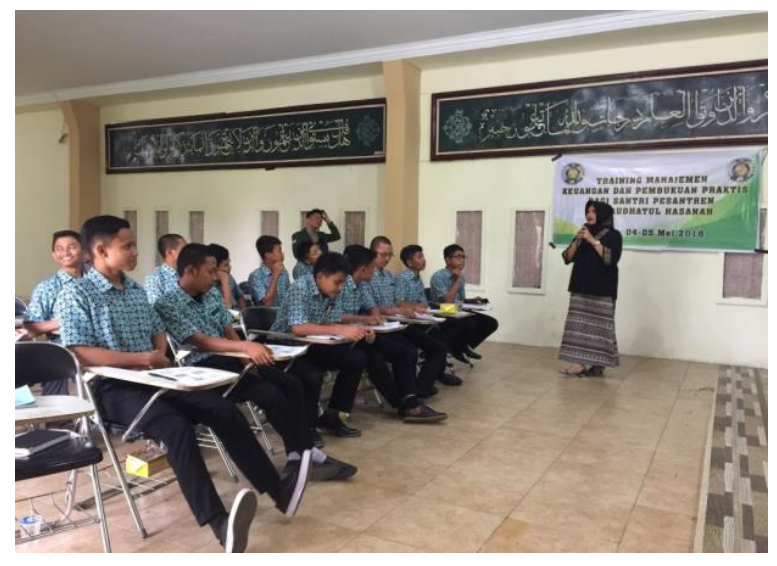

3.1 management finance training and practical bookkeeping

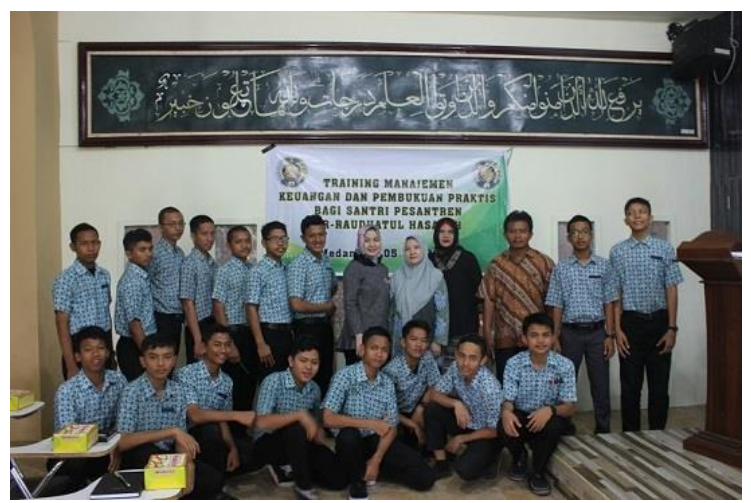

3.2 the participant of management finance training and practical bookkeeping

\section{PARTNER PARTICIPATION}

Partners involved in training were the students (santri) that has been given the responsibility to run santri mart and the student stores, they were students who sat in XI grade, they were very enthusiastic with the training and gave many feedbacks, also knowledge that they gain from the training could be implemented in the student's daily activity. With this entrepreneurship training hopefully it can motivate students to live a better quality life without damaging the environment. 
Aisyah. et al. Business Management and Entrepeneurship for the Santri At Pesantren Ar-Raudhatul Hasanah Medan.

The next post training activity is monitoring and assisting to see the development of business management knowledge by making bookkeeping, marketing methods, and entrepreneurship along with implementing it in a few weeks after being received by the trainees. Assistance is carried out with joint evaluation activities to find out in addition to the development as well as the difficulties experienced so that mentoring has a positive learning impact, then a reeducation will be held or refreshing the system of knowledge and skills in business management so that developments done substantively and technically become more tangible.

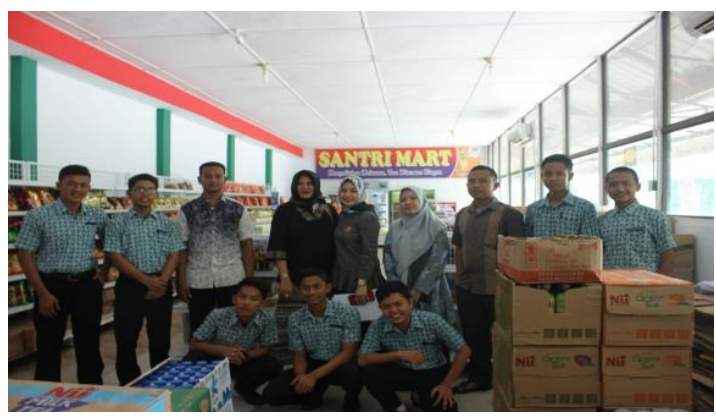

4.1 partner location for the act of devotion

\section{RESULT AND DISCUSION}

The implementation of organization imposed by Pesantren Raudhatul Hasanah can be classified in the medium criteria. This was caused by several weaknesses in the practice of organizing. Such as the division in a double section of the business unit, as well as leaders who have the same authority in decision making.

Leadership is done together, therefore it could cover the shortcomings between one other especially leadership in managing a business. With a unified whole, the process of directing, motivating, and guiding can be done well. Thus, the practice of leadership in Pesantren Raudatul Hasanah is classified as good. Moreover, charismatic leaders have their own power in carrying out all the pesantren activities.
Overall, the management of business units in Pesantren Raudhatul Hasanah has good quality. All managers in the field of charity, foundation, business unit management and employees are in for a goal that is integrated in one system. It can be said that the management of Pesantren Ar-Raudatul Hasanah business units are the All in one system, namely that all economic activities are in a system that synergizes and integrates to realize the vision and mission in the school's value.

With the implementation of management functions in the running of the business units in Pesantren Ar-Raudhatul Hasanah, the results obtained are: The organizational mechanism is going well; Know the constraints and problems in the business units; Look for solutions to problems that exists within the business units; There is financial accountability and transparency between business units; Minimize failure and optimize success; Economic business becomes a medium of learning and experience; The creation of economic independence in Pesantren. The success of the Pesantren Raudhatul Hasanah in managing their business units builds its own characteristics. The management characteristics of the business units in Pesantren Ar-Raudhatul Hasanah are:

1. Planning are based on the pesantren's values.

2. Organizing based on regeneration

3. Transformative collective leadership

4. Total Quality Control.

In the implementation process, the management characteristics forms the general characteristics, which are:

a. Implementation of Learning by Doing on business unit activities

b. Implementation of Self Berdruing System

c. Centralized Finance; also the creation of a balanced physical and mental well-being. Pesantren Raudatul Hasanah seems exclusive in developing existing business units. 
Preferably, there could be cooperation in terms of economic development of the local community.

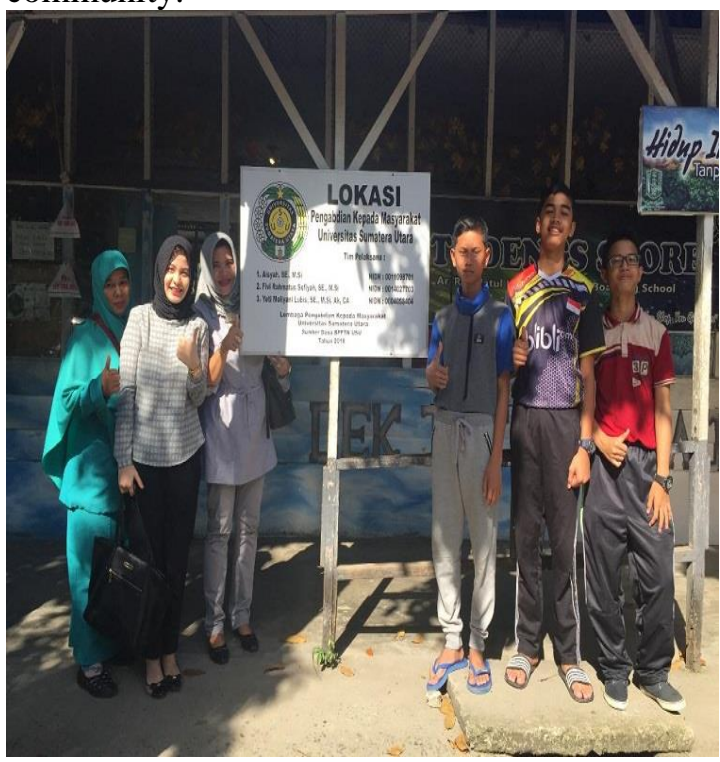

5.1. the signpost installation at the location of devotion

Being an entrepreneur must start at an early age. This is due to the fact that at a young age the enthusiasm is still very much there and immense, creative and innovation power is soaring as well as the energy owned. To create young entrepreneurs it can be done in various ways. One of them is through formal education in schools. Formal schools as an educational institution are trusted by the community can be a useful place in growing entrepreneurial talent. Therefore, other than being equipped with general knowledge, they are also equipped with soft skills in the form of entrepreneurship.

There are various positive reasons as to why entrepreneurship becomes an important part in the learning process. First, with being equipped with entrepreneurship, the santri can better understand the business to run it, suitably with their talents and interests. This can help the government in reducing unemployment. Second, the more young people have entrepreneurship, the greater the potential for government tax revenue. Third, building enthusiasm to keepbeing innovative in producing products, thus providing many choices for the community. Fourth, when the product pioneered was successful, entrepreneurs will open new branches and some even start to establish new businesses.

\section{CONCLUSION}

Overall, the management of business units in Pesantren Ar-Raudatul Hasanah has good quality, however the application of business management in managing the businesses is still very simple because the knowledge of the students as managers is still limited. The existence of these various business units becomes an education medium in the fields of independence, entrepreneurship, sincerity, and sacrifice. All business units owned by the boarding school is managed by the students (santri) and teachers, the outcome is used to meet the needs of the boarding school, students, and teachers

\section{ACKNOWLEDGEMENT}

Thank you to the Community Service Institute of the University of North Sumatra for the financial support and facilities provided in the Community Devotion Act NON PNBP University of North Sumatera In accordance with the Letter of Agreement of Community Devotion Act for the Mono Program as of the Year 2018 with the Number :176/UN5.2.3.2.1/PPm/2018, April $16^{\text {th }} 2018$.

\section{REFERENCES}

Brigham, Eugene $\mathrm{F}$ and Joel F Houston, (2004), Fundamentals of Financial Management, 10e, International Student Edition, Thomson Learning.

Kotler., Philip et.al. (2013). Marketing Management : An Asian Perfektive (Sixth Edition). Singapore: Pearson. 
Aisyah. et al. Business Management and Entrepeneurship for the Santri At Pesantren Ar-Raudhatul Hasanah Medan.

Kraus.,(2015).
$\begin{aligned} & \text { 2.Jakarta.Andi } \\ & \text { Sutojo, siswanto, }\end{aligned}$
$\begin{aligned} & \text { Penjualan } \\ & \text { Pustaka }\end{aligned}$

Tjiptono., F., \& Gregorius. C. (2016). Service Quality \& Satisfaction, Edisi 4, Yogyakarta: Andi

Van Horne, James and John M. Machowics, JR, (2001), Pinciple of Financial Management, Prentice Hall. 